\title{
NANOCELLULOSE-REINFORCED PHENOL-FORMALDEHYDE RESIN FOR PLYWOOD PANEL PRODUCTION
}

\author{
Elaine Cristina Lengowski, ${ }^{1, \star}$ \\ https://orcid.org/0000-0002-7336-7626 \\ Eraldo Antonio Bonfatti Júnior ${ }^{2}$ \\ https://orcid.org/0000-0002-2730-7681 \\ Rafael Dallo \\ https://orcid.org/0000-0002-6192-9265 \\ Silvana Nisgoski ${ }^{2}$ \\ https://orcid.org/0000-0001-9595-9131 \\ Jorge Luís Monteiro de Mattos ${ }^{2}$ \\ https://orcid.org/0000-0003-3388-5258 \\ José Guilherme Prata \\ https://orcid.org/0000-0002-6479-9160
}

\begin{abstract}
The search for new technologies to improve adhesives and the properties of reconstituted wood panels is constant, and nanotechnology is a tool for this purpose. The aim of this study is investigating the effect of adding nanocellulose in the formulation of the adhesive phenol-formaldehyde on the physico-mechanical properties of Pinus taeda plywood panels. Three ratios of nanofibrillated cellulose (NFC) were added to the adhesive formulation used to produce plywood panels: $0,026 \% ; 0,038 \%$ or $0,064 \%$. The panels were tested according to the European standards; apparent density, resistance to parallel and perpendicular flexure and glue line shear strength were determined after 6 hours of boiling and after the boiling cycle for the $1^{\text {st }}$ glue line (face) and $2^{\text {nd }}$ glue line (core). The use of NFC in the adhesive caused an increase of viscosity and reduction of the gel time of the adhesive. The apparent density of the panels was not influenced by the addition of NFC, but the properties of parallel bending, perpendicular flexing and glue line shear were sensitive to the addition of NFC. The NR2 treatment $(0,038 \%$ NFC) presented the best results in the mechanical tests.
\end{abstract}

Keywords: Glue line shear test, mechanical properties, nanotechnology, nanofibrillated cellulose, plywood, Pinus taeda 


\section{INTRODUCTION}

The use of solid wood presents some disadvantages because it is heterogenous and anisotropic (Torquato 2002, Fratzl and Weinkamer 2007, Buligon 2015), and in many cases the mechanical properties of wood are unsatisfactory for certain uses (Song et al. 2018). In addition, due to natural defects or the tree's own growth, there is a limitation of dimensions for many uses (Maloney 1993). Therefore, the production of wood panels can be a more rational use of this raw material (Carvalho 2016).

Wood panels are composites that use wood and adhesives as bonding agents, to improve the characteristics of the raw material (Lengowski et al. 2019). Plywood panels are composed of overlapping wood sheets bonded with adhesives, mainly phenol-formaldehyde and urea-formaldehyde, under high pressure and temperature, with the fibers (grain) crossed at an angle of $90^{\circ}$ (Yuce et al. 2014).

Resin represents the third highest industrial cost, which leads to constant research for improved adhesives in terms of performance and economy (Eichhorn et al. 2010, Gindl-Altmutter and Veigel 2014). One kind of improvement is the reinforcement of adhesives with nanocellulose. Resin reinforced with nanocellulose has been identified as promising, among various improvements offered by nanotechnology in the forest products industry (Candan and Akbulut 2015). Various applications have provided improvement in both the physical and mechanical properties of panels (Gindl-Altmutter and Veigel 2014).

Nanocelluloses are cellulosic materials having at least one dimension in nanometric scale. Nanocelluloses can be produced by different methods and from various lignocellulosic sources (Abdul Khalil et al. 2014). Nanofibrilatted cellulose (NFC) is a kind of nanocellulose produzed by a homogenization or grinding process, with diameter between $5 \mathrm{~nm}$ and $30 \mathrm{~nm}$ and amorphous and crystalline zones composing their structure (Sehaqui et al. 2011, Rojas et al. 2015, Samyn et al. 2018). Due to the small size, nanomaterial has properties such as high aspect ratio, crystallinity and surface area, excellent mechanical properties combined with less weight, along with better biodegradability than solid wood (Eichhorn et al. 2010, Mondragon et al. 2015).

Therefore, this work evaluates the effect of NFC addition on the phenol-formaldehyde adhesive and the physico-mechanical properties of Pinus taeda plywood panels.

\section{MATERIAL AND METHODS}

\section{Material}

The panels were made by Dallo Madeiras Ltda., a company located in the city of Três Barras, Santa Catarina, Brazil. The analysis and production of nanofibrillated cellulose (NFC) as well as the quality tests of the adhesives and panels were carried out at Federal University of Paraná.

The nanocellulose used was NFC dispersed in $1 \%$ aqueous solution, produced from bleached cellulose of Eucalyptus sp. It has a mean diameter of $22,28 \mathrm{~nm}$ and a variable length in the micrometer scale, considered as nanomaterial and nano-object according to ISO standards ISO/TS 20477 (2017).

The phenol-formaldehyde resin used was produced by the company Hexion and marketed under the name Cascophen HL- $7090 \mathrm{Hs}$, with solids content of $52,4 \%$, gel time at $121^{\circ} \mathrm{C}$ of 8 minutes, $\mathrm{pH}$ of 12 and Brockfield viscosity of $455 \mathrm{cp}$ (LVF $2 / 60 / 25^{\circ} \mathrm{C}$ ). In addition to the resin, wheat flour was used as extender, with Ford viscosity cup number 8 of 25 seconds.

The veneers used are produced from Pinus taeda wood with 2,8 $\mathrm{mm}$ thickness dried in an industrial dryer until reaching average moisture content of $8 \%$ in the core and $12 \%$ on the face, the higher moisture content in the face veneers are needed to allow heat conduction from the press into the panel and also to prevent pre-curing of the adhesive.

\section{Adhesive formulation and characterization}

The solids content of the adhesive was set at $26,7 \%$ for all compositions. The phenol-formaldehyde resin, extender, water and NFC were used to compose the adhesive according to the formulations described in Table 1. 
Table 1: Adhesive formulations.

\begin{tabular}{|c|c|c|c|c|}
\hline Component & CA & NR1 & NR2 & NR3 \\
\hline Resin (\%) & 50,640 & 50,640 & 50,640 & 50,640 \\
\hline Extender (\%) & 23,820 & 23,820 & 23,820 & 23,820 \\
\hline Water (\%) & 25,640 & 25,614 & 25,602 & 25,576 \\
\hline NFC (\%) & 0,000 & 0,026 & 0,038 & 0,064 \\
\hline
\end{tabular}

CA: control adhesive; NR: nano-reinforced adhesive.

For viscosity determination, a Ford Cup \#8 was used, in which the cup was filled with the adhesive and the flow time was measured until the first interruption in the flow through the bore of the cup, in accordance with ASTM D1200-18 (2018).

About $1,0 \mathrm{~g}$ of adhesive was placed in a $15,0 \mathrm{~cm} \times 2,0 \mathrm{~cm}$ test tube, which was dipped in a glycerin bath at $120{ }^{\circ} \mathrm{C}$. The gelatinization time for each adhesive sample was measured from dipping in the glycerin bath until partial adhesive hardening, verified when it offered greater resistance to the rotation of the glass stick, in accordance with ASTM D2471-99 (1999).

The $\mathrm{pH}$ was determined with a digital $\mathrm{pHmeter}$, at a temperature of $25^{\circ} \mathrm{C}$, calibrated to $\mathrm{pH} 4$ and 7 using standard buffer solutions. Approximately $200 \mathrm{~mL}$ of the adhesives was used in three replicates, following the ASTM E70-07 (2015).

\section{Production and characterization of panels}

The wood veneers of Pinus taeda used had dimensions of $600 \mathrm{~mm} \times 600 \mathrm{~mm} \times 2,8 \mathrm{~mm}$. The panels were produced with five layers, the resins being applied to one side of the veneer with a weight of $380 \mathrm{~g} \cdot \mathrm{cm}^{-2}$ (double line). The panels were pressed at a temperature of $140^{\circ} \mathrm{C}$, with specific pressure of $11 \mathrm{kgf} \cdot \mathrm{cm}^{-2}$ for 12 minutes. Three panels were produced per treatment, totaling 12 panels analyzed.

After pressing, the panels were conditioned in a climatic chamber at a temperature of $20{ }^{\circ} \mathrm{C} \pm 3{ }^{\circ} \mathrm{C}$ and relative humidity of $65 \% \pm 5 \%$. The samples for tests of apparent density, static (parallel and perpendicular) flexure and glue line shearing (dry test, 6 hours' boiling and boiling cycle) were cut according to the requirements of EN 310-93 (1993a), EN 314-2-93 (1993b) and EN 323-93 (1993c). The shear tests were performed on the $1^{\text {st }}\left(\right.$ face) and $2^{\text {nd }}($ core) glue line (Figure 1).
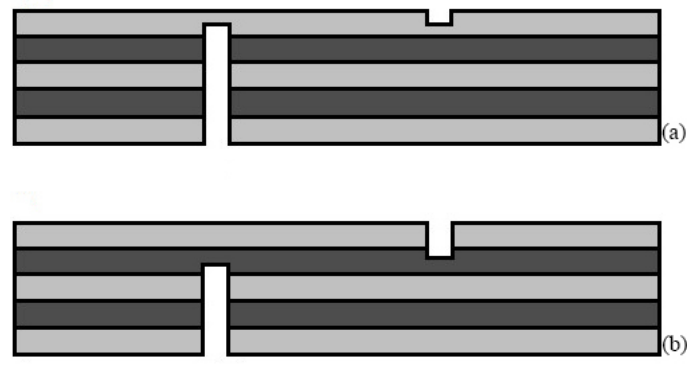

Figure 1: Side view of the test specimens for the glue line shear test. (a) $1^{\text {st }}$ glue line, (b) $2^{\text {nd }}$ glue line. 


\section{Data analysis}

Tests of homogeneity and analysis of variance (ANOVA) were performed, and when significant difference was detected between treatments, the Tukey test was used, at $5 \%$ significance. The data were analyzed with the statistical software Statgraphics (2019).

\section{RESULTS AND DISCUSSION}

\section{Adhesive characterization}

The mean results of the control adhesive and adhesives reinforced with NFC are shown in Table 2.

The addition of nanocellulose to the adhesives affected significantly the physico-chemical properties, except for $\mathrm{pH}$, which remained practically constant for all adhesives ( $p$-value $=0,0521)$. In general, the percentage increase of nanocellulose in the adhesives caused an increase significant in the viscosity $(p$-value $=$ $0,0000)$ and decrease in the gel time $(p$-value $=0,0000)$.

Table 2: Properties of control adhesive and adhesives with different additions of NFC.

\begin{tabular}{|c|c|c|c|c|}
\hline Property & CA & NR1 & NR2 & NR3 \\
\hline Viscosity (s) & $127 \mathrm{a}(1,57)$ & $69 \mathrm{~b}(4,35)$ & $63 \mathrm{c}(1,58)$ & $53 \mathrm{~d}(1,08)$ \\
\hline Gel time (s) & $518 \mathrm{a}(2,52)$ & $384 \mathrm{~b}(2,36)$ & $363 \mathrm{bc}(0,57)$ & $349 \mathrm{c}(5,29)$ \\
\hline $\mathrm{pH}$ & $11,7 \mathrm{a}(1,77)$ & $12,2 \mathrm{a}(1,64)$ & $12,1 \mathrm{a}(1,72)$ & $11,8 \mathrm{a}(0,85)$ \\
\hline
\end{tabular}

CA: control adhesive; NR: nano-reinforced adhesive.

Means followed by the same letter in the column are statistically the same by the Tukey test at $95 \%$ confidence; values in parentheses indicate the coefficient of variation.

Viscosity is one of the most important properties of an adhesive (Din et al. 2018), and this feature depends on the temperature (generally decreasing with rising temperature of the liquid) and its composition (Peschel et al. 2016). The viscosity of the adhesive increased with the addition of NFC: for NR1, the viscosity increased by $45 \%$, for NR2 by $50 \%$ and for NR3 by $58 \%$ in relation to the control sample, indicating that small amounts of NFC modify this property. The viscosity of fluids comes from the internal friction of the particles, which are influenced by the forces of attraction between molecules. Since NFC has many free hydroxyl groups to form bonds, the force of attraction influenced the viscosity. The increase in viscosity has a negative influence on the penetration of the adhesive, so that when the viscosity is high, the uniform distribution of the adhesive on the wood is difficult, with insufficient penetration into the wood structure, impairing wetting and leaving a line of thick glue with low mechanical resistance (Gonçalvez and Lelis 2009).

Mahrdt et al. (2016) and Cui et al. (2014) found that the addition of nanocelulose in urea-formaldehyde resin caused an increase in the viscosity of the adhesive, a result similar to the one found in this work. Damásio et al. (2017), Ferreira (2017) and Liu et al. (2015) observed a change in the viscosity of adhesives with addition of nanocrystalline cellulose (CNC), and this change was linked only to the physical interaction between the adhesive and the nanocellulose, since no chemical reaction between the adhesive and $\mathrm{CNC}$ was observed. According to Gindl-Altmutter and Veigel (2014), the large increase of the viscosity caused by the addition of nanocellulose can represent a serious obstacle to resin spraying and impregnation in the wood.

The gel time of the adhesives changed with increasing NFC content, with reductions of $26 \%$ for adhesive NR1, $32 \%$ for NR2 and $33 \%$ for NR3 relative to the control adhesive. The addition of NFC caused a decrease in the gel time, indicating that the working time of the adhesives was reduced and that a shorter pressing time would be required for cure of the adhesive. Shorter working time makes it harder to apply and spread the adhesive in the wood due to its rapid polymerization, causing a decrease in the strength of the glue line (Cunha 2016). In industrial settings, shorter gel times are aimed at reducing the pressing time, resulting in increased 
productivity and reduced energy consumption.

Cui et al. (2014) produced nanofibrillated cellulose (NFC) reinforced particle boards and observed increased gel time of a tannin-based adhesive with the addition of NFC (1\% to $3 \%$ ). Mahrdt et al. (2016) found a delay in the formation of the chemical and mechanical bonding during resin curing, unlike what was found here for phenol-formaldehyde resin. However, they also found that the addition of MFC allowed better distribution of the adhesive in the wood, with less formation of clots (which weakens the bond), besides presenting the same penetration in the wood.

The $\mathrm{pH}$ of the adhesives remained practically constant, preserving the chemical characteristic of the adhesive used. Since the mechanical production of NFC occurs only with the addition of water, the pH of NFC does not change. Unlike the use of $\mathrm{CNC}$, which because acids are used in their production have a slightly acid charge, the addition of NFC can delay or accelerate the cure depending on the adhesive type, due to the change of $\mathrm{pH}$ (Gindl-Altmutter and Veigel 2014).

\section{Plywood characterization}

Table 3 shows the average results of the specific gravity at $12 \%$ moisture of the plywood obtained from the different treatments.

Table 3: Mean results of specific gravity of plywood.

\begin{tabular}{|c|c|}
\hline Treatment & Specific gravity $\left(\mathbf{k g} \cdot \mathbf{m}^{-\mathbf{3}}\right)$ \\
\hline CA & $486 \mathrm{a}(4,5)$ \\
\hline NR1 & $477 \mathrm{a}(4,8)$ \\
\hline NR2 & $476 \mathrm{a}(6,1)$ \\
\hline NR3 & $457 \mathrm{a}(5,8)$ \\
\hline
\end{tabular}

CA: control adhesive; NR: nano-reinforced adhesive.

Means followed by the same letter in the column are statistically the same by the Tukey test at $95 \%$ confidence; values in parentheses indicate the coefficient of variation.

The specific gravity of the plywood did not show significant variation after the addition of the NFC in the adhesive $(p$-value $=0,0635)$.

The specific gravity of plywoood is related to the density of the raw material, the adhesive solids content, as well as amount of resin in the glue line. Since there was no variation in the adhesive solids and the amount of resin placed in each treatment, the variation found was associated with the variability in the density of the Pinus taeda veneers. The specific gravity produced was below the specific gravity of the panels produced with $100 \%$ Pinus taeda by Iwakiri et al. (2018), which presented specific gravity of $600 \mathrm{~kg} \cdot \mathrm{m}^{-3}$, and ABIMCI (2017) for commercial Pinus plywood, from 490 to $560 \mathrm{~kg} \cdot \mathrm{m}^{-3}$. This result is related to the quality of the raw material: wood with higher specific gravity results in panels with higher specific gravity (Iwakiri et al. 2012).

Table 4 shows the average results of the parallel and perpendicular static bending of the plywood obtained for the different treatments.

Statistical difference was observed between the parallel static bending treatments for MOE ( $\mathrm{p}$-value $=$ 0,0128 ) and MOR ( $\mathrm{p}$-value $=0,0027$ ). The mean values of MOE and MOR strength for parallel static bending ranged from 4425,27 $\mathrm{MPa}$ to 2734,60 $\mathrm{MPa}$ and from 37,74 $\mathrm{MPa}$ to 24,23 $\mathrm{MPa}$. The parallel static bending strength of the panels was statistically equal to the control for the NR1 and NR2 treatments, demonstrating that the bonding was not impaired with the addition of the NFC in these treatments. However, a significant reduction of $38,18 \%$ in these properties was observed for the treatment with highest addition of NFC in the glue composition (NR3). On perpendicular static bending, a statistically significant difference was observed between the treatments for the MOE ( $\mathrm{p}$-value $=0,0091$ ) while the MOR showed no significant dif- 
ference ( $\mathrm{p}$-value $=0,1149$ ). For perpendicular static bending, the MOE ranged between 1599,54 MPa and $1146,00 \mathrm{MPa}$ and MOR between 22,54 MPa and 17,04 MPa. For this analysis, only MOE presented statistical difference, where the NR1 treatment was equal to the control treatment and the lowest values for this property were found for the highest levels of NFC adittion (NR2 and NR3).

Table 4: Mean results of static bending test of plywood.

\begin{tabular}{|c|c|c|c|c|}
\hline \multirow{2}{*}{ Treatment } & \multicolumn{2}{|c|}{ Parallel } & \multicolumn{2}{c|}{ Perpendicular } \\
\cline { 2 - 5 } & MOE (MPa) & MOR (MPa) & MOE (MPa) & MOR (MPa) \\
\hline $\mathrm{CA}$ & $4425,27 \mathrm{a}(14,7)$ & $36,62 \mathrm{a}(14,9)$ & $1599,54 \mathrm{a}(13,5)$ & $21,22 \mathrm{a}(15,5)$ \\
\hline $\mathrm{NR} 1$ & $3440,45 \mathrm{ab}(23,4)$ & $32,74 \mathrm{ab}(20,6)$ & $1263,02 \mathrm{ab}(16,6)$ & $19,14 \mathrm{a}(28,9)$ \\
\hline $\mathrm{NR} 2$ & $3301,27 \mathrm{ab}(25,2)$ & $37,74 \mathrm{a}(13,4)$ & $1146,00 \mathrm{~b}(20,4)$ & $17,04 \mathrm{a}(10,3)$ \\
\hline NR3 & $2734,60 \mathrm{~b}(24,9)$ & $24,23 \mathrm{~b}(22,1)$ & $1196,22 \mathrm{~b}(19,3)$ & $22,54 \mathrm{a}(18,6)$ \\
\hline
\end{tabular}

CA: control adhesive; NR: nano reinforced adhesive. MOE: modulus of elasticity; MOR: modulus of rupture. Means followed by the same letter in the column are statistically the same by the Tukey test at $95 \%$ confidence; values in parentheses indicate the coefficient of variation.

The parallel static bending results for the NR1 and NR2 treatments were statistically equal to the control (CA), demonstrating that the bonding was not impaired with the addition of NFC. Adding a higher NFC content (NR3) impaired the parallel static bending. For resistance to perpendicular static bending, the MOE of the NR1 treatment was equal to the control treatment (CA), whereas the MOR was statistically equal in all treatments.

Besides the specific gravity, the static bending of plywood panels is influenced by the quality of the raw material used in the production of the veneers. Wood with higher specific gravity results in panels with greater resistance to static bending (Iwakiri et al. 2012). The values found in this work are below those reported by Ross (2010), which states that the parallel MOE of Pinus sp. is $7700 \mathrm{MPa}$ and the parallel MOR is 37,09 MPa. The values found are also below the values reported by ABIMCI (2017) for plywoods of Pinus sp. marketed in Brazil, for which parallel MOE varies between $4876 \mathrm{MPa}$ and $8921 \mathrm{MPa}$; parallel MOR between 23,4 MPa and 52,7 MPa; perpendicular MOE between $1903 \mathrm{MPa}$ and $3774 \mathrm{MPa}$; and perpendicular MOR between 15,8 $\mathrm{MPa}$ and 34,8 $\mathrm{MPa}$.

Table 5 shows the average values of glue line shear strength in the dry tests, after 6 hours of boiling and the boiling cycle of the plywood samples.

Table 5: Mean results of glue line shear strength.

\begin{tabular}{|c|c|c|c|c|c|c|}
\hline \multirow{2}{*}{ Treatment } & \multicolumn{2}{|c|}{$\begin{array}{c}\text { Shear strength - dry } \\
\text { (MPa) }\end{array}$} & \multicolumn{2}{c|}{$\begin{array}{c}\text { Shear strength - 6 h } \\
\text { (MPa) }\end{array}$} & \multicolumn{2}{c|}{$\begin{array}{c}\text { Shear strength - } \\
\text { cycle (MPa) }\end{array}$} \\
\cline { 2 - 7 } & Core & Face & Core & Face & Core & Face \\
\hline \multirow{2}{*}{$\mathrm{CA}$} & $1,32 \mathrm{~b}$ & $1,28 \mathrm{ab}$ & $1,20 \mathrm{~b}$ & $0,75 \mathrm{a}$ & $0,98 \mathrm{c}$ & $0,64 \mathrm{a}$ \\
& $(17,4)$ & $(22,4)$ & $(32,4)$ & $(25,9)$ & $(42,0)$ & $(37,6)$ \\
\hline \multirow{2}{*}{$\mathrm{NR} 1$} & $2,45 \mathrm{a}$ & $1,30 \mathrm{ab}$ & $1,31 \mathrm{ab}$ & $0,63 \mathrm{a}$ & $1,00 \mathrm{bc}$ & $0,49 \mathrm{a}$ \\
& $(22,3)$ & $(22,1)$ & $(28,7)$ & $(42,3)$ & $(36,7)$ & $(49,9)$ \\
\hline & $2,30 \mathrm{a}$ & $1,50 \mathrm{a}$ & $1,37 \mathrm{ab}$ & $0,72 \mathrm{a}$ & $1,42 \mathrm{a}$ & $0,63 \mathrm{a}$ \\
$\mathrm{N} 2$ & $(23,9)$ & $(23,9)$ & $(36,7)$ & $(25,5)$ & $(30,3)$ & $(45,3)$ \\
\hline & $2,26 \mathrm{a}$ & $1,09 \mathrm{~b}$ & $1,55 \mathrm{a}$ & $0,58 \mathrm{a}$ & $1,33 \mathrm{ab}$ & $0,70 \mathrm{a}$ \\
$\mathrm{NR} 3$ & $(13,4)$ & $(23,6)$ & $(24,3)$ & $(35,9)$ & $(28,7)$ & $(25,9)$ \\
\hline
\end{tabular}

CA: control adhesive; NR: nano reinforced adhesive.

Means followed by the same letter in the column are statistically the same by the Tukey test at $95 \%$ confidence; values in parentheses indicate the coefficient of variation. 
$\mathrm{MPa}$ (NR2), while for $2^{\text {nd }}$ glue line it varied between 1,32 MPa (AC) and 2,45 MPa (NR2). The percentages of failure of the wood varied from $63 \%$ to $89 \%$ for the $1^{\text {st }}$ glue line and from $69 \%$ to $95 \%$ for the $2^{\text {nd }}$ glue line. Although the treatments of core $(p$-value $=0,000)$ and face $(p$-value $=0,0063)$ presented statistical difference between them, all treatments presented average shear strength values above the minimum value of 1,0 MPa established by EN 314-2-93 (1993b).

After boiling for 6 hours, the average shear values varied for the $1^{\text {st }}$ glue line from $0,58 \mathrm{MPa}$ (NR3) to 0,75 $\mathrm{MPa}(\mathrm{CA})$ and for the $2^{\text {nd }}$ glue line ranged between 1,20 MPa (CA) and 1,55 MPa (NR3). The percentages of failure in the wood varied from $16 \%$ to $32 \%$ for the $1^{\text {st }}$ glue line and from $60 \%$ to $83 \%$ for the $2^{\text {nd }}$ glue line. Only the core glue line test result met the requirements laid down in EN 314-2-93 (1993b). Statistically there were differences between treatments for the $2^{\text {nd }}$ glue line $(p$-value $=0,0421)$, whereas for the $1^{\text {st }}$ glue line the treatments were statistically similar $(p$-value $=0,0555)$.

The shear strength after the boiling cycle varied for the $1^{\text {st }}$ glue line from $0,49 \mathrm{MPa}$ (NR1) to $0,70 \mathrm{MPa}$ (NR3) and for the $2^{\text {nd }}$ glue line from $0,98 \mathrm{MPa}(\mathrm{CA})$ to $1,42 \mathrm{MPa}$ (NR2). The percentages of faults in the wood ranged from $20 \%$ to $39 \%$ for the $1^{\text {st }}$ glue line and from $47 \%$ to $69 \%$ for the $2^{\text {nd }}$ glue line. Again, only the core glue line result met the requirements laid down in EN 314-2-93 (1993b). Statistically the behavior was similar to the pre-treatment of 6 hours of boiling, in which there was difference between treatments for the tests of the $2^{\text {nd }}$ line of glue $(p$-value $=0,0013)$ whereas for the $1^{\text {st }}$ glue line the treatments were statistically equal $(p$-value $=0,1061)$.

There was improvement in shear strength of the glue line with the addition of nanocellulose to the $2^{\text {nd }}$ glue line, whereas for the $1^{\text {st }}$ glue line only the dry test presented a significant gain. In general, the NR2 treatment presented the best result for all shear tests of the $2^{\text {nd }}$ glue line.

The use of NFC improved the interaction of the adhesive with the wood, with greater resistance in relation to the control sample. There was an increase of $85,6 \%$ for the NR1 adhesive in the core in the dry shear test. For the NR2 adhesive, the highest gains were for the face in the dry shear tests $(17,18 \%)$ and the core after 72 hours of boiling $(44,89 \%)$. NR3 adhesive produced the highest gains for the core shear test after 6 hours of boiling $(29,16 \%)$, while the gains after 72 hours of boiling in the core were $35,71 \%$ and $9,37 \%$ on the face. These results indicate that higher NFC contents improve properties under more severe test conditions of plywood, while lower NFC contents can be employed to improve panels that will not be exposed to severe conditions. Despite the improvement in shear strength for the face after 6 hours and the boiling cycle with the addition of NFC, none of the treatments met the requirements of EN 314-2-93 (1993b).

The reduction of face shear strength with increased NFC content may have occurred due to the lower penetration of the adhesive into the veneer because of the increase in the viscosity of the adhesives. Pre-curing of the adhesive during pre-pressing of the panels may also have occurred due to the reduction of the gel time with the addition of NFC. Combined effects occur during the static bending test. Traction, compression and shear stress simultaneously change when the sample is subjected to the static bending stress. The decrease in shear strength of the face glue line with increased NFC content influenced the static bending strength, since this is one of the resistance forces that can cause the increase of the static bending property.

Zhang et al. (2011) found a $23,6 \%$ increase in static bending property of the urea-formaldehyde resin (UF) glue line with addition of $1,5 \%$ CNC modified with APTES in the glue line of plywood panels. CNC values above $1,5 \%$ cause the formation of nanocellulose clusters that lead to a decline of this property. Eichhorn et al. (2010) found significant gains when $5 \%$ CNF was added to UF adhesive for the production of bonded joints. The addition of CNF of $0,5 \%$ to $5 \%$ to UF resin allowed a significant gain in stress and strength until composite failure. The researchers attributed this increase to the absence of cracks, commonly observed in UF glue lines.

\section{CONCLUSIONS}

The addition of NFC to the adhesive caused an increase in the viscosity and decrease of the gel time, while the $\mathrm{pH}$ remained constant.

The application of the nanocellulose caused improvement of the rheological properties of the adhesive and can decrease the cost of the adhesive. 
The plywood's specific gravity was not altered with the addition of NFC to the adhesive.

There was a reduction in static bending properties for the parallel MOE and MOR and perpendicular MOR of the panels made with the adhesive with $0,064 \% \mathrm{NFC}$ and, for perpendicular MOE with use of the adhesives with $0,038 \%$ and $0,064 \%$ NFC.

All plywood panels conformed with the minimum strength requirements of the European standard for core glue line shear strength. For the face veneer, only the dry test results were in accordance with the required shear strength.

In general, the best results of the mechanical properties of the panels were obtained with $0,038 \%$ NFC in the adhesive.

Since the addition of NFC alters the rheological properties, especially the viscosity, which in turn interferes with the penetration of the adhesive in the wood, new formulations must be tested in order to maintain the viscosity commonly employed by plywood manufacturers.

\section{ACKNOWLEDGEMENTS}

We thank Dallo Madeiras Ldta. for cooperation in the execution of this project; the University of Contestado and the Foundation to Support Research and Innovation of Santa Catarina State for the financial support. Also, we are grateful to the Wood Technology and the Anatomy and Quality of Wood Laboratories of Federal University of Paraná for their assistance in the analysis.

\section{REFERENCES}

Abdul Khalil, H.P.S.; Davoudpour, Y.; Nazrul Islam, M.D.; Mustapha, N.; Sudesh, K.; Dungani R.; Jawaid, M. 2014. Production and modification of nanofibrillated cellulose using various mechanical processes: a review. Carbohydr Polym 99: 649-665. https://doi.org/10.1016/j.carbpol.2013.08.069

ASTM. 2018. Standard Test Method for Viscosity by Ford Viscosity Cup. ASTM D1200-18. 2018. ASTM International: West Conshohocken, PA. http://www.astm.org/cgi-bin/resolver.cgi?D1200-10(2018)

ASTM. 1999. Standard Test Method for Gel Time and Peak Exothermic Temperature of Reacting Thermosetting Resins (Withdrawn 2008). ASTM D2471-99.1999. ASTM International: West Conshohocken, PA. http://www.astm.org/cgi-bin/resolver.cgi?D2471-99.

ASTM. 2015. Standard test method for $\mathrm{pH}$ of aqueous solutions with the glass electrode. ASTM E70-07. 2015. ASTM International: West Conshohocken, PA. http://www.astm.org/cgi-bin/resolver.cgi?E70-19

ABIMCI. 2017. Painéis de compensado de pinus, Catálogo Técnico. < http://www.abimci.com.br/wp-content/uploads/2014/02/Catalogo_Tecnico_Compensado_Pinus.pdf $>$

Buligon, E.A. 2015. Physical and mechanical properties of laminated veneer lumber reinforced. Ciência Florestal 25(3): 731-741. http://www.bioline.org.br/abstract?cf15068

Candan, Z.; Akulut, T. 2015. Physical and mechanical properties of nanoreinforced particleboard composites. Maderas-Cienc Tecnol 17(2): 319-334. http://dx.doi.org/10.4067/S0718-221X2015005000030

Carvalho, M.Z. 2016. Multivariate approach to the behavior of physical-chemical properties and characterization of natural adhesives based on tannins. PhD Thesis, Federal University of Lavras, Lavras, Brazil.

Cui, J.; Lu, X.; Zhou, X.; Chrusciel, L.; Deng, Y.; Zhou, H.; Zhu, S.; Brosse, N. 2014. Enhancement of mechanical strength of particleboard using environmentally friendly pine (Pinus pinaster L.) tannin adhesives with cellulose nanofibers. Ann For Sci 72(1): 27-32. https://doi.org/10.1007/s13595-014$0392-2$ 
Cunha, R.C.B. 2016. Implementation of a method for measuring Gel Time of formaldehyde-based resins. Master Thesis, Higher Institute of Engineering of Porto, Porto, Portugal.

Damásio, R.A.P.; Carvalho, F.J.B.; Carneiro, A.C.O.; Ferreira, J.C.; Colodette, J.L. 2017. Effect of CNC interaction with urea-formaldehyde adhesive in bonded joints of Eucalyptus sp. Sci For 45(113): 169-176. http://www.ipef.br/publicacoes/scientia/

Din, Z.U.; Xiong, H.; Wang, Z.; Chen, L.; Ullah, I.; Fei, P.; Ahmad, N. 2018. Effects of different emulsifiers on the bonding performance, freeze-thaw stability and retrogradation behavior of the resulting high amylose starch-based wood adhesive. Coll Surf A 538(5): 192-201. https://doi.org/10.1016/j.colsurfa.2017.11.002

Eichhorn, S.J.; Dufresne, A.; Aranguren, M.; Marcovich, N.E.; Capadona, J.R.; Rowan, S.J.; Weder, C.; Thielemans, W.;Roman, M.; Renneckar, S.; Gindl, W.; Veigel, S.; Keckes, J.; Yano, H.; Abe, K.; Nogi, M.; Nakagaito, A.N.; Mangalam, A.; Simonsen, J.; Benight, A.S.; Bismarck, A.; Berglund, L.A; Peijs, T. 2010. Review: current international research into cellulose nanofibres and nanocomposites. $J$ Mater Sci 45(1): 1-33. https://doi.org/10.1007/s10853-009-3874-0

EN. 1993a. Determination of modulus of elasticity and modulus of rupture in static bending. EN 310-93. 1993. ECS: Brussels. https://standards.cen.eu/

EN. 1993b. Plywood. Bonding quality. Requirements. EN 314-2-93. 1993. ECS: Brussels. https://standards.cen.eu/

EN. 1993c. Determination of density. EN 323-93. 1993. ECS: Brussels. https://standards.cen.eu/

Ferreira, J.C. 2017. Synthesis of urea-formaldehyde adhesives with the addition of kraft lignin and nanocrystalline cellulose. PhD Thesis, Federal University of Viçosa, Viçosa, Brazil. https://www.locus. ufv.br/bitstream/handle/123456789/10010/texto\%20completo.pdf?sequence=3\&isAllowed=y

Fratzl, P.; Weinkamer, R. 2007. Nature's hierarchical materials. Prog Mater Sci 52(8): 1263-1334. https://doi.org/10.1016/j.pmatsci.2007.06.001.

Gindl-Altmutter, W.; Veigel, S. 2014. Nanocellulose-modified Wood Adhesives. In: Handbook of Green Materials. Oksman, k.; Mathew, A.P.; Bismarck, A.; Rojas, O.; Sain, M. (Eds.). World Scientific Publishing Co Pte Ltd: Singapure. 17: 253-264.

Gonçalvez, F.G.; Lelis, R.C.C. 2009. Properties of two synthetic resins after addition of modified tannin. Floram 16(2): 01-07. https://www.floram.org/article/588e221ce710ab87018b4664

ISO/TS. 2017. Nanotechnologies. Standard terms and their definition for cellulose nanomaterial. ISO/TS 20477.2017. https://www.iso.org/standard/68153.html

Iwakiri, S.; Matos, J.L.M.; Ferreira, E.S.; Prata, J.G.; Trianoski, R. 2012. Produção de painéis compensados estruturais com diferentes composições de lâminas de Eucalyptus saligna e Pinus caribea. Rev Arvore 36(3): 596-576. https://doi.org/10.1590/S0100-67622012000300019

Iwakiri, S.; Trianoski, R.; Vieira, H.C.; Andrade, R.; Rocha, T.M.S.; Ferreira, V.R.S. 2018. Viability of the use of wood of Cupressus torulosa for plywood production. Sci For 46(120): 638-645. https://www.ipef.br/publicacoes/scientia/nr120/cap12.pdf

Lengowski, E.C.; Bonfatti Júnior, E.A.; Kumode, M.M.N.; Carneiro, M.E.; Satyanarayana, K.G. 2019. Nanocellulose-Reinforced Adhesives for Wood-Based Panels. In Sustainable Polymer Composites and Nanocomposites. Thomas, S.I.; Kumar, R.; Mishra, A.M.A. (Eds:). 1001-1025. Springer International Publishing. https://www.springerprofessional.de/en/nanocellulose-reinforced-adhesives-for-wood-based-panels/16438260

Liu, Z.; Zhang, Y.; Wang, X.; Rodrigue, D. 2015. Reinforcement of lignin-based phenol-formaldehyde adhesive with nano-crystalline cellulose (NCC): curing behavior and bonding property of plywood. Mater Sci Appl 6: 567-575. https://www.scirp.org/html/12-7701515_57456.htm

Mahrdt, E.; Pinkl, S.; Schmidberger, C.; Van Herwijnen, H.W.G.; Veigel, S.; Gindl-Atmutter, W. 
2016. Effect of addition of microfibrillated cellulose to urea formaldehyde on selected adhesive characteristics and distribution in particle board. Cellulose 23(1): 571-580. https://doi.org/10.1007/s10570-015$0818-5$

Maloney, T.M. 1993. Modern particleboard \& dry-process fiberboard manufacturing. 2nd ed. Miller Freeman: San Francisco. USA

Mondragon, G.; Peña-Rodriguez, C.; Gonzáles, A.; Eceiza, A.; Arbelaiz, A. 2015. Bionanocomposites based on gelatin matrix and nanocellulose. Eur Polym $J$ 62: 1-9. https://doi.org/10.1016/j.eurpolymj.2014.11.003

Peschel, P.; Hornhardy, E.; Nennewitz, I.; Nutsch, W.; Schulzig, S.; Seifert, G.; Strechel, T. 2016. Tabellenbuch Holztechnik. Europa-Lehrmittel Nourney: Vollmer GmbH \& Co. Haan-Gruiten, Germany. https://www.europa-lehrmittel.de/downloads-leseproben/41814-9/3027.pdf

Rojas, J.; Bedoya, M.; Ciro, Y. 2015. Current trends in the production of cellulose nanoparticles and nanocomposites for biomedical applications. In Cellulose - Fundamental Aspects and Current Trends. Poletto, M.; Ornaghi, H.L. (Eds.). InTech Publisher: Rijeka. Chapter. 8: 193-228. https://doi.org/10.5772/61334

Ross, R.J. 2010. Wood handbook: wood as an engineering material. USDA Forest Service, Forest Products Laboratory, General Technical Report FPL-GTR-190. 509 p. https://doi.org/10.2737/FPL-GTR-190

Samyn, P.; Barhoum, A.; Öhlund, T.; Dufresne, A. 2018. Review: nanoparticles and nanostructured materials in papermaking. J Mater Sci 53(1): 146-184. https://doi.org/10.1007/s10853-017-1525-4

Sehaqui, H.; Allais, M.; Zhou, Q.; Berglund, L.A. 2011. Wood cellulose biocomposites with fibrous structures at micro-and nanoscale. Compos Sci Technol 171(3): 382-387. https://doi.org/10.1016/j.compscitech.2010.12.007

Song, J.; Chen, C.; Zhu, S.; Zhu, M.; Daí, J.; Ray, U.; Li, Y.; Kuang, Y.; Li, Y.; Quispe, N.; Yao, Y.; Gong, A.; Leiste, U.H.; Bruck, H.A.; Zhu, J. Y; Vellore, A.; Li, H.; Minus, M.L.; Jia, Z.; Martini, A.; Li, T.; Hu, L. 2018. Processing bulk natural wood into a high-performance structural material. Nature 554 (7691): 224-228. https://doi.org/10.1038/nature25476

Statgraphics. 2019. Statgraphics 19. Statgraphics Technologies, Inc. https://www.statgraphics.com/.

Torquato, S. 2002. Random Heterogeneous Materials. Microstructure and Macroscopic Properties. Springer: Berlin, Germany. https://doi.org/10.1007/978-1-4757-6355-3

Yuce, B.; Mastrocinque, E.; Packianather, M.S.; Pham, D.; Lambiase, A.; Fruggiero, F. 2014. Neural network design and feature selection using principal component analysis and Taguchi method for identifying wood veneer defects. Prod Manuf Res 2(1): 291-308. http://dx.doi.org/10.1080/21693277.2014.892442

Zhang, H.; Zhang, J.; Shong. S.; Wu, G.; Pu, J. 2011. Modified nanocrystalline cellulose from two kinds of modifiers used for improving formaldehyde emission and bonding strength of urea-formaldehyde resin adhesive. BioResources 6(4): 4430-4438 https://ojs.cnr.ncsu.edu/index.php/BioRes/article/view/BioRes_06_4_4430_Zhang_ZSWP_Mod_Nanocrystalline_Cellulose_CH2O_UF_Adhesive 